УДК 611.885 .013

О.Д. Сапунков, О.М. Слободян*, Ю.В.Товкач*, В.В. Кривецький **

Кафедри дитячої хірургї та отоларингології (зав. - проф. О.Б. Боднар); *анатомії, топографічної анатомії та оперативної хірургії (зав. - проф. О.М. Слободян); **анатомії людини імені М.Г. Туркевича (зав. - проф. В.В. Кривеиький) ВДНЗ Украйни “Буковинський державний медичний університет", м. Чернівиі

\title{
БУДОВА СЕРЕДНЬОГО ВУХА У ПЛОДІВ ЛЮДИНИ 7-ГО МІСЯЦЯ ВНУТРІШНЬОУТРОБНОГО РОЗВИТКУ
}

Резюме. Будова та синтопія середнього вуха вивчені у 11 плодів людини сьомого місяця внутрішньоутробного розвитку. Встановлено, що в цей період відсутні нижня та передня стінки барабанної порожнини, не сформований надбарабанний простір. Барабанні отвори слухових труб знаходяться в нижній частині барабанної порожнини, а глоткові отвори - на рівні твердого піднебіння. Печера соскоподібного відростка та канал лицевого нерва не мають дефінітивних розмірів i розташування їх відрізняється від такого у новонароджених.

Ключові слова: анатомія, барабанна порожнина, слухова труба, печера соскоподібного відростка, канал лицевого нерва. 
У наш час мікроопераційні технології і повна візуалізація структур барабанної порожнини у багатократному збільшенні дозволили підвищити якість операцій та знизити ризик можливих ускладнень [1]. А прицільна робота на даних структурах вимагає точного знання анатомотопографічних особливостей будови скроневої кістки, в тому числі й у дитячому віці [2].

У сучасній літературі достатньо докладно описані будова, варіанти будови, вади барабанної порожнини $[3,4]$ і можливі оперативні підходи в цій ділянці, але тільки в поодиноких роботах можна зустріти дані про вікові анатомічні особливості будови структур барабанної порожнини. У літературі ми не зустріли даних про розміри структур середнього вуха, окрім повідомлення, що у дітей 1-го - 3-го років життя товщина нижньої стінки барабанної порожнини складає 0,3-1,0 мм. Між іншим, ці показники мають велике значення при хірургічних маніпуляціях на середньому вусі у ранньому віці [1]. Це пов'язано з тим, що за останні 10 років у розвинутих країнах відсоток передчасно народжених дітей залишається стабільним i складає 5-12 \% всіх новонароджених, які мають власні анатомо-фізіологічні особливості, що потребують вивчення. Адже незрілість органів і систем цих дітей, важкість їх адаптації часто призводять до розвитку патологічних симптомокомплексів, у тому числі і з боку органа слуху, що може викликати необхідність хірургічного втручання [5].

Ось чому вивчення ембріологічних аспектів розвитку середнього вуха, його анатомії та топографічної анатомії у плодів залишається актуальним.

\section{Мета}

дослідження:

3'ясувати топографоанатомічні особливості середнього вуха у плодів 7-ми місяців внутрішньоутробного розвитку та обгрунтувати морфологічний взаємозв'язок його формоутворювальних процесів з прилеглими структурами.

Матеріал і методи. Дослідження виконано на 11 плодах людини 231,0-270,0 мм тім'янокуприкової довжини (ТКД). У ході дослідження використовували методи: тонкого препарування середнього вуха та прилеглих ділянок під контролем бінокулярної лупи; макро- та мікроскопії; морфометрії; макрофотографії uифровим фотоапаратом "OLIMPUS $\mu 1000$ Allweather 10,0 MPix".

Результати дослідження та їх обговорення. У плодів сьомого місяця внутрішньоутробного життя барабанна порожнина не має нижньої та передньої стінок, вона має клиноподібну форму. Надбарабанний простір є розширеною частиною клина, який утворився при цьому. Барабанна порожнина обмежена 3 верхньоприсереднього боку лабіринтною стінкою, 3 верхньобічногопокрівельним відростком кам'янистої частини. Товщина іiі складає $0,71 \pm 0,03$ мм (рис. 1).

Вікно присінка має бобоподібну форму. Вікно завитки має овальну або кулясту форму. Ка-нал лицевого нерва проходить над вікном присінка $\mathrm{i}$ НЕ Сапунков О.Д., Слободян О.М., Товкач Ю.В., Кривецький В.В., 2016

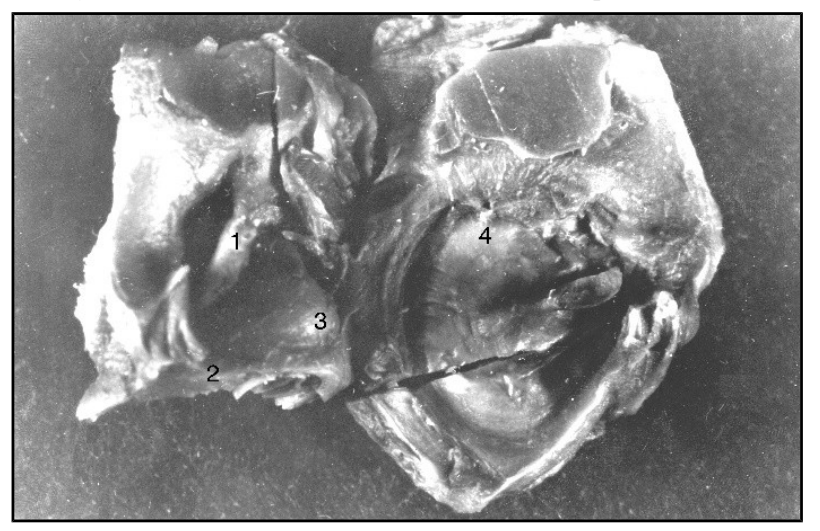

Рис. 1. Сагітальний розріз барабанної порожнини плода 265,0 мм ТКД. 3б. 1:3,8: 1 - вікно присінка, 2 -

мис, 3 - вікно завитки, 4 - барабанна перетинка

має кісткової стінки. Слухова труба пряма, широка, має циліндричну форму. Кістковий відділ і перешийок у неї відсутні. Спостерігалась неправильна, трикутна та прямокутна форми барабанних отворів слухових труб, які розташовані в нижньому відділі барабанної порожнини (рис. 2). Глоткові отвори слухових труб розташовані на рівні твердого піднебіння (рис. 3).

Печера соскоподібного відростка (рис. 4) розташована поверхнево під кірковим шаром,

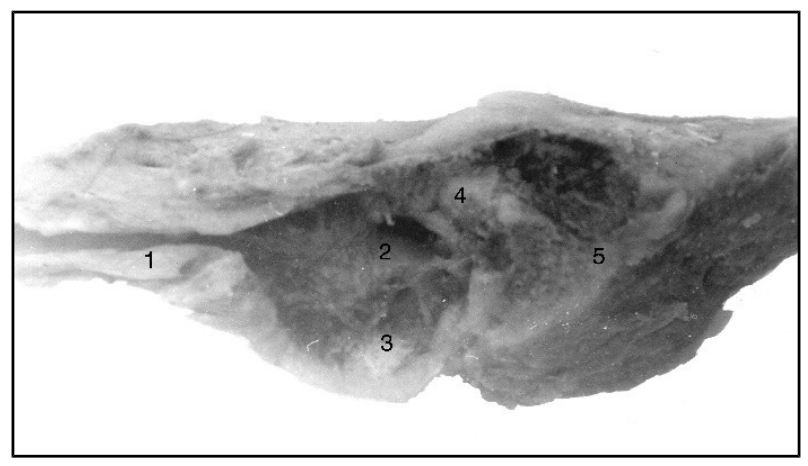

Рис. 2. Сагітальний розріз скроневої кістки плода 240,0 мм ТКД. 3б. 1:3,2: 1 - слухова труба, канал внутрішньої сонної артерії, 2 - вікно присінка, 3 вікно завитки, 4 - канал лицевого нерва, 5 - печера соскоподібного відростка 


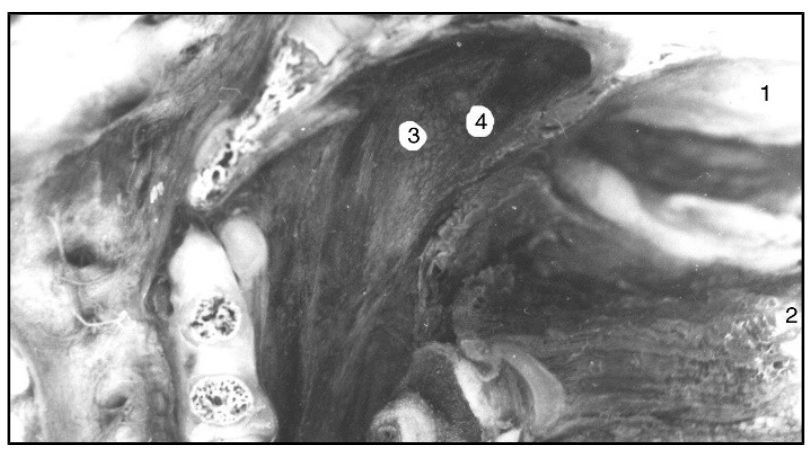

Рис. 3. Сагітальний розріз голови плода 235,0 мм ТКД. 3б. 1:3,2: 1 - ротова порожнина, 2 -язик, 3 носоглотка, 4 - глотковий отвір слухової труби

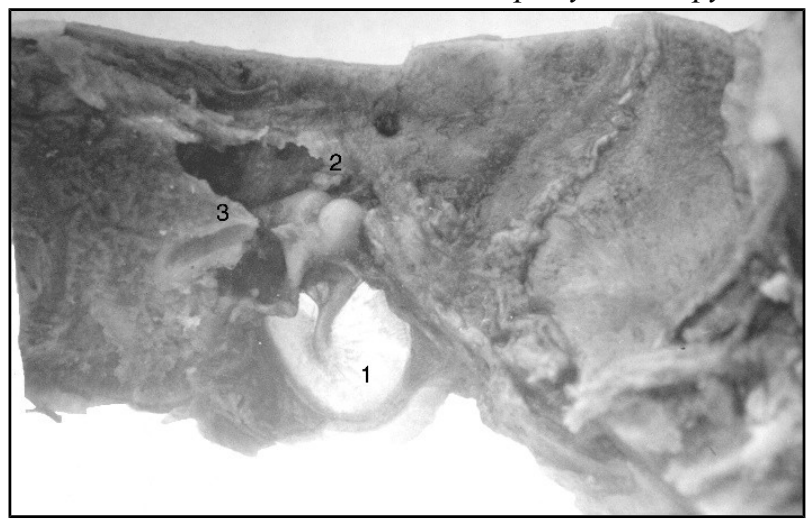

Рис. 4. Сагітальний розріз голови плода 255,0 мм

ТКД. 3б. 1:3,2: 1 - барабанна перетинка, 2 надбарабанний закуток, 3 - печера соскоподібного відростка

товщина якого складає $1,05 \pm 0,05$ мм. На зовнішній поверхні соскоподібного відростка наявна лусковососкоподібна щілина, що заповнена сполучною тканиною. Передня стінка печери міститься на рівні заднього краю барабанного кільця, а нижня стінка - вище рівня його верхнього краю на $1,84 \pm 0,07$ мм.

Верхня стінка печери відокремлює іiі від середньої черепної ямки, товщина стінки становить $0,62 \pm 0,02$ мм. Печера має бобоподібну форму і такі розміри: довжину - 5,25 $\pm 0,16$ мм, висоту $-3,25 \pm 0,14$ мм, ширину $-4,10 \pm 0,12$ мм. Діаметр входу до печери становить $1,54 \pm 0,03$ мм. Спостерігалась його бобоподібна форма або форма чотиригранної піраміди. Канал внутрішньої сонної артерії проходить під кутом $35^{\circ}$ до основи черепа $\mathrm{i}$ розміщений на нижньовнутрішній поверхні скроневої кістки. Діаметр канала внутрішньої сонної артерії складає $0,93 \pm 0,03$ мм. Ширина яремної ямки становить 5,52 $\pm 0,21$ мм, довжина - 6,03 $\pm 0,22$ мм (рис. 5).

Барабанна порожнина має наступні розміри: довжина знизу $-6,55 \pm 0,25$ мм, довжина на рівні мису $-8,35 \pm 0,38$ мм, довжина зверху $-5,45 \pm 0,23$ мм. Вертикальні розміри барабанної порожнини:

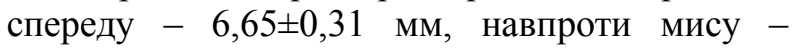

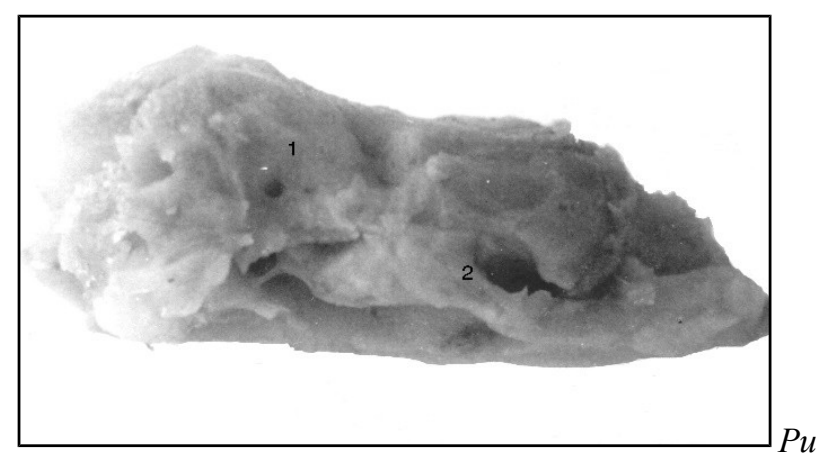

c. 5. Скронева кістка плода 235,0 мм ТКД (вид знизу).

3б. 1:3,2: 1-яремна ямка, 2 - канал внутрішньої сонної артерії

$8,50 \pm 0,33$ мм, позаду $-6,34 \pm 0,29$ мм.

Ширина барабанної порожнини: в

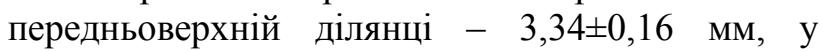
верхньозадній - 3,42 $\pm 0,14$ мм. Вертикальний розмір вікна присінка становить $1,35 \pm 0,06$ мм, горизонтальний $-2,16 \pm 0,09$ мм. Середній

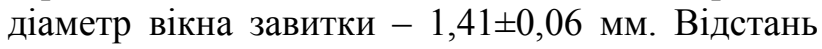
між вікном завитки та вікном присінка становить $0,87 \pm 0,03$ мм. Довгий діаметр барабанного кільця 3 барабанною перетинкою становить 7,52 $\pm 0,27$ мм, короткий діаметр - 6,54 $\pm 0,25$ мм. Вертикальний розмір мису на лабіринтній стінці становить 4,02 $\pm 0,18$ мм. Канал лицевого нерва проходить над вікном присінка під кутом $33^{\circ}$. Його довжина складає $4,16 \pm 0,18$ мм, діаметр $0,83 \pm 0,02$ мм.

Довжина слухової труби становить $11,52 \pm 0,37$ мм, діаметр - 1,08 $\pm 0,03$ мм. Вертикальний розмір барабанних отворів слухових труб - 2,94 $\pm 0,12$ мм, горизонтальний $2,12 \pm 0,06$ мм. Передньозадній розмір глоткових отворів слухових труб - 1,64 $\pm 0,08$ мм, вертикальний $-2,12 \pm 0,09$ мм.

Висновки та перспективи подальших досліджень. 1. У плодів даного віку відсутні нижня та передня стінки барабанної порожнини, не сформований надбарабанний простір. 2. Печера соскоподібного відростка не має дефінітивних розмірів i розташування ii відрізняється від такого у новонароджених. 3. Барабанні отвори слухових труб розміщені в нижній частині барабанної порожнини, а глоткові отвори - на рівні твердого піднебіння. 4. Канал лицевого нерва не має кісткової стінки i розташування його відрізняється від такого у новонароджених. 5. Визначені особливості мають важливе значення при удосконаленні технологій і адекватності хірургічного лікування 
та маніпуляцій у передчасно народжених дітей. 


\section{Список використаної літератури}

1. Богомильский М.Р. Особенности строения лабиринтной стенки барабанной полости в раннем детском возрасте / М.Р. Богомильский, М.М. Полунин // Вестн. отоларинголог. - 2010. - № 3. - С. 6667. 2. Cinamon $U$. The growth rate and size of the mastoid air cell system and mastoid bone: a review and reference / U. Cinamon // European Archives Oto-Rhino-Laryngology. - 2009. - V. 266, Iss. 6. - P. 781-786. 3. Ontogenetic landmarks of the organ of hearing in fetal age determination / George Lupu, Daniel Popescu, Victor Panus, Gabriela Popescu // Rom. J. Leg. Med. - 2010. - № 2. - P. 129-132. 4. Tamrazi B. Imaging of Pediatric Hearing Loss / Benita Tamrazi, Jeevak Almast, Rajiv Mangla // Neurographics. - 2011. - V. 1, № 2. - Р. 66-73. 5. Важность исследования ЛОР-органов у недономенных детей / И.В. Рахманова, Р.В. Котов, О.А. Бабак, В.В. Раш // Вестн. отоларинголог. - 2010. - № 3. - С. 12-14. 


\section{СТРОЕНИЕ СРЕДНЕГО УХА ПЛОДОВ ЧЕЛОВЕКА СЕДЬМОГО ВНУТРИУТРОБНОГО РАЗВИТИЯ}

Резюме. Строение и синтопия среднего уха изучены у 11 плодов человека седьмого месяца внутриутробного развития. Установлено, что в этот период отсутствует нижняя и передняя стенки барабанной полости,не сформировано надбарабанное пространство. Барабанные отверстия слуховых труб расположены в нижней части барабанной полости, а глоточные отверстия находятся на уровне твердого неба. Пещера сосцевидного отростка и канал лицевого нерва не имеют дефинитивных размеров и расположение их отличается от такового у новорожденных.

Ключевые слова: анатомия, барабанная полость, слуховая труба, пещера сосцевидного отростка, канал лицевого нерва.

\section{STRUCTURE OF THE MIDDLE EAR OF THE HUMAN FETUSES SEVEN MONTHS OF THE DEVELOPMENT}

Abstract. The structure of the middle ear and syntopy studied in 11 human fetuses seven months of development. It was established that during this period no bottom and front wall of the tympanic cavity is not formed nadbarabannyy space. Barabanni auditory tube openings are at the bottom of the drum porozhnyny and pharyngeal openings at the hard palate. Cave mastoid and facial nerve canal are not definitive size and the location of their different location in the newborn.

Key words: anatomy, tympanic cavity, auditory tube, the cave of the mastoid process, the facial nerve canal. 
State Higher Educational Establishment in Ukraine "Bukovinian State Medical University" (Chernivtsi)

Надійшла 02.06.2016 p. Рецензент - проф. Олійник І.Ю. (Чернівці) 